\title{
Degradation mechanisms and evaluation of failure of gas pipelines
}

\author{
G. Dundulis*, A. Grybėnas**, R. Janulionis***, R. Kriūkienė****, S. Rimkevičius ${ }^{* * * * * *}$ \\ *Lithuanian Energy Institute, Breslaujos str. 3, 44403 Kaunas, Lithuania, E-mail: Gintautas.Dundulis@lei.lt \\ **Lithuanian Energy Institute, Breslaujos str. 3, 44403 Kaunas, Lithuania, E-mail: Albertas.Grybenas@lei.lt \\ ***Lithuanian Energy Institute, Breslaujos str. 3, 44403 Kaunas, Lithuania, E-mail: Remigijus.Janulionis@lei.lt \\ ****Lithuanian Energy Institute, Breslaujos str. 3, 44403 Kaunas, Lithuania, E-mail: Rita.Kriukiene@lei.lt \\ *****Lithuanian Energy Institute, Breslaujos str. 3, 44403 Kaunas, Lithuania, E-mail: Sigitas.Rimkevicius@lei.lt \\ cross ${ }^{\text {ref }}$ http://dx.doi.org/10.5755/j01.mech.21.5.10196
}

\section{Introduction}

Natural gas is main energy resource that is necessary for industry and citizens. The demand and consumption of natural gas is relatively big and for gas supply the network of pipelines is used in Lithuania and the World. Disruption of gas supply can have disastrous consequences to all over the country and even continent-wide (remembering the year 2009, when the gas supply from Russia to Europe has been disrupted), so it is very important to ensure that the gas transmission networks would be as reliable as possible. Reliable network - it is not only a reliable gas supply. Failures and their consequences mostly are more expensive than prevention of failures so reliable network is also important for network operators to minimize network maintenance costs.

Reliability of natural gas transmission system is closely linked to a number of factors that could affect the structural integrity of the systems and influencing their operational service life. Transmission and distribution network failures during operation, cause problems for not only supplying of energy resources, but also are potentially dangerous to human safety and structures due to possible explosions. Therefore, it is important to know the actual operational conditions of these systems, influence of different failures on reliability of one or another part of the system and possible disruption of gas supply.

Analysis of failure causes in the world shows that significant part of gas transmission pipeline incidents are due to the condition of materials and processes that take place in their operation and affects the structural integrity of these systems. Gas pipeline failures related to the corrosion and defects in materials are responsible for about 40$60 \%$ of all failures. Another part of pipeline failures are related to the impact of external factors, such as execution of engineering works during pipeline operation, technological process management errors, unauthorized excavation works and other actions, as well as effect of natural external forces [1-12].

Experimental research and pipeline operation data [13-20] shows, that pipe metal is ageing due to diffusion processes. This occurs at nanostructural level. Formation of the intergranular networks of carbon-hydride like compounds at grain boundaries during the ageing of pipe steel is one of the main reasons causing the change of material properties and creating favourable conditions for formation of structures with defects, initiation of stress corrosion and rise of intensity of electrochemical processes that cause corrosion.
Another and the most important factor limiting the service lifetime of pipelines is the impact of external environmental conditions and operating parameters associated with the stresses. Analysis of pipeline failure causes showed that they are usually associated with corrosion mechanical mechanisms [9, 14, 21-28], where the most dangerous is Stress Corrosion Cracking (SCC) [22-26]. Primary defects in the inner or outer pipeline surface are the necessary condition for SCC. SCC is initiated under mechanical stresses and corrosion environment in construction elements of the pipeline at cathodically protected pipe surface, so it is difficult to predict. The formation of crack is typical for SCC process, which shows as brittle inter- or trans- granular fracture of metal. Due to accumulation of large elastic energy in the pipe wall the developing crack cause pipeline explosion that may extend from ten to one hundred meters and even more [9, 27]. For example, such pipe fracture is dominant cause of OAO Gazprom gas transmission pipeline accidents (see Fig. 1).

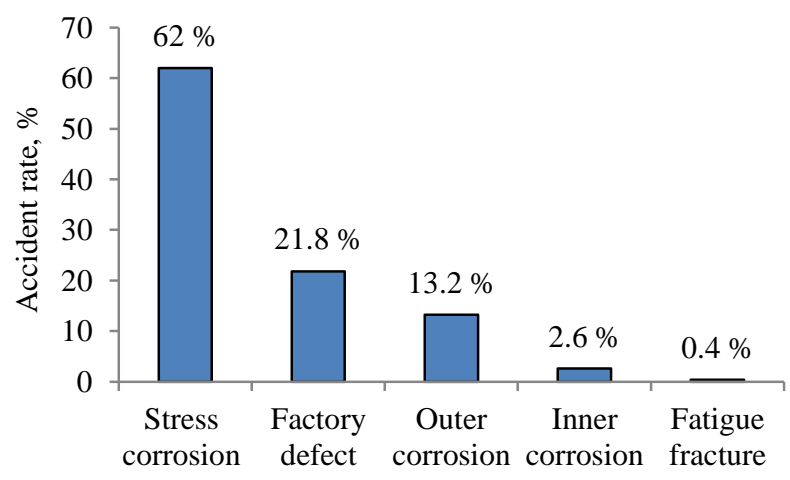

Fig. 1 Accident rate of gas transmission pipelines due to causes (according to OAO Gazprom data for 19912005 time period [11])

Analysis of pipeline failure causes also shows that other often reasons causing pipe damage, especially, through-wall defect formation, are pitting corrosion $[9,21]$, damage caused by cyclic loading where corrosionfatigue mechanism appears (usually in welding zone) [21, 24,28], and under particular conditions - hydrogen absorption (hydrogen brittleness) [29-31] and microbiological corrosion [9, 32, 33]. Indicated degradation mechanisms are mostly caused by the same electrochemical processes and stress. Therefore, they are related and occurrence of one or another process depends on specific conditions that must be assessed according to status of operating pipeline and environmental effects. 
Available Lithuanian gas transmission pipelines statistical data related to their characteristics and damages are presented and summarized in this article. It is necessary to note that from 1961 not all data have remained, especially in the case of older gas pipe maintenance period up to 1995. Therefore, the statistical analysis data on failure rate and causes of failures are not complete. To determine the impact of aging effect on mechanical properties and fracture parameters of pipeline steel which has been in service the experimental tests of pipe samples were carried out. Using experimentally determined mechanical properties and fracture parameters the analysis of acceptable and critical crack sizes, was performed at operational load case. Typical defects determined in pipelines according their formation mechanisms were used in this analysis.

\section{Evaluation of degradation mechanisms of Lithuanian gas transmission pipelines}

The gas transmission pipelines mostly were built between 60-ies and 80-ies of XX century in Lithuania. In Lithuania the pipelines were built using the same pipes, pipe surface coating materials, as well as engineering works and pipeline operation technology and technical regulations as in Russia. This is due to the fact that the system has always been associated with Russian pipelines.

The construction of gas transmission pipeline in Lithuania has started in 1961. The change of overall length of Lithuanian gas transmission pipeline in time is presented in Fig. 2. In 2013 the transmission pipeline JurbarkasKlaipeda has been finished. Technical parameters of this transmission pipeline: length $\sim 138 \mathrm{~km}$, diameter $400 \mathrm{~mm}$, maximal pressure $-5.4 \mathrm{MPa}$. Two new gas distribution stations were built in Jurbarkas (2007) and Klaipeda (2013), LNG terminal connection to gas transmission system was installed. The length of Lithuanian gas transmission pipeline at the present time is over $2000 \mathrm{~km}$. However, compared with other countries, the length of Lithuanian gas pipeline network is relatively modest (Table 1). For example, Western Europe (EGIG [4]) network length reached 130 thousand km, and Russian 175 thousand km.

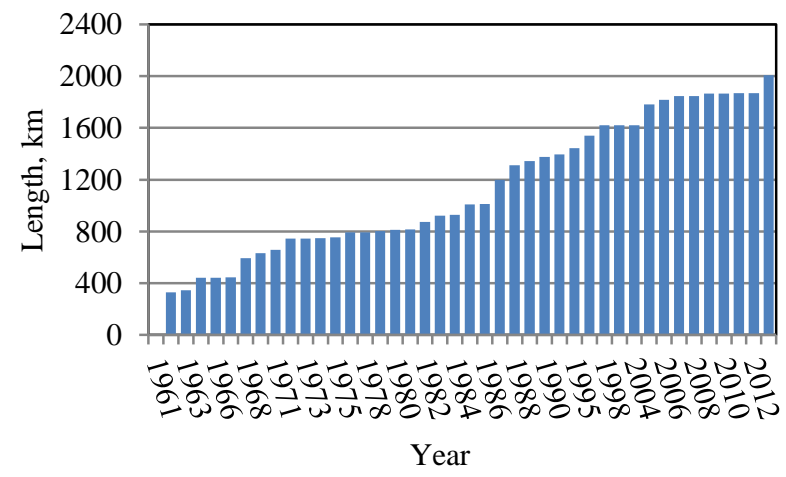

Fig. 2 The change of overall length of Lithuanian gas transmission pipeline in time

From 2013 AB Amber Grid, as the operator of Lithuanian natural gas transmission system, is in charge of the safe operation, maintenance and development of the transmission system. The transmission system is comprised of gas transmission pipelines, gas compressor stations, gas metering and distribution stations, cathodic protection systems installed to prevent corrosion of the pipeline, remote data transmission and telecommunication systems (Table 1).

Table 1

Basic elements of gas transmission system

\begin{tabular}{|l|l|l|l|}
\hline $\begin{array}{l}\text { Gas trans- } \\
\text { mission } \\
\text { pipelines }\end{array}$ & $\begin{array}{l}\text { Gas distribu- } \\
\text { tion stations }\end{array}$ & $\begin{array}{l}\text { Gas metering } \\
\text { stations }\end{array}$ & $\begin{array}{l}\text { Gas com- } \\
\text { pressor sta- } \\
\text { tions }\end{array}$ \\
\hline $2007 \mathrm{~km}$ & 66 stations & 3 stations & 2 stations \\
\hline
\end{tabular}

Lithuanian natural gas transmission system (Fig. 3) is interconnected with the natural gas transmission systems of Belarus, Latvia and Russia. The largest volumes of natural gas are imported via the gas transmission pipeline from Belarus and are transported to customers of Lithuania and in transit to customers of the Kaliningrad Region, Russian Federation. Gas transportation via the Lithuania Latvia cross-border gas interconnector is bidirectional.

At present time mixed one-pipe and two-pipe network system is installed in Lithuania. As it shown in system diagram (see Fig. 3) the two-pipe system are installed in sections Vilnius-Ryga, Panevėžys-Šiauliai and Vilnius-Kaliningrad. Other sections Šiauliai-Klaipeda, Minsk-Vilnius, Šakiai-Klaipedda has one pipe. Before the LNG terminal was installed the gas was supplied from Belarus. Therefore, the pipeline section Minsk-Vilnius was extremely important, because any accident in this line could lead to the termination of gas supply and gas transit suspension.

Fig. 4 shows the distribution of Lithuanian and, for comparison, European gas transmission pipeline depending on their operating time. It can be seen that age of the transmission systems are similar. The average age of the pipelines was 27.5 years in 2009 in Lithuania and 29 years in Western Europe. However, it should be noted that almost $40 \%$ of the Lithuanian gas transmission pipelines are more than 36 years old and it means that these pipelines are 3 years older than the conditional normative life provided during construction, which is 33 years.

The largest pipe diameter of Lithuanian gas transmission pipeline is $1220 \mathrm{~mm}$. Fig. 5 shows the pipeline distribution by pipe diameter. It shows that $30 \%$ of all pipeline is built of $700 \mathrm{~mm}$ diameter pipe. $64 \%$ of pipeline is built of pipes which diameter is $400 \mathrm{~mm}$ or more. Smaller diameter distribution pipelines mainly depend to branches passing to distribution stations. Comparing by this technological parameter, most of the pipelines in Russia $(65 \%)$ consists of pipelines with a diameter higher than $1000 \mathrm{~mm}$, while more than half $(53 \%)$ in the Western European gas transmission pipeline (by EGIG) diameter is less than $500 \mathrm{~mm}$.

The design pressure of biggest part of Lithuanian gas transmission pipeline is 54 bar. Western European pipelines (by EGIG) maximum gas pressure is from 16 to over 75 bar. $70 \%$ of the high-pressure piping consists of pipes which operating pressure is over 66 bars. Russian gas transmission systems dominated pipelines (60\%) which maximum design pressure is $55-75$ bar. 

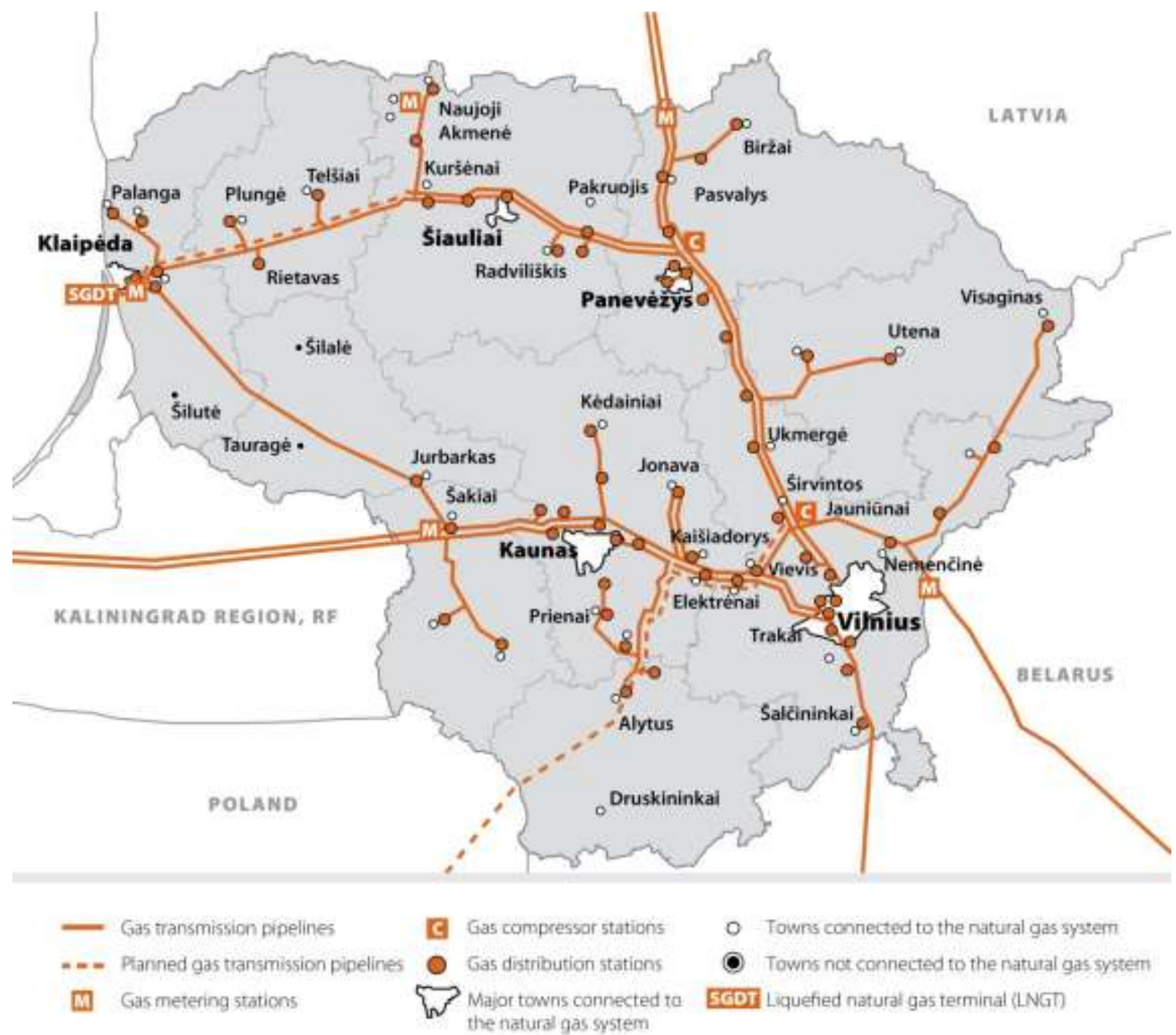

Fig. 3 Lithuanian natural gas transmission system

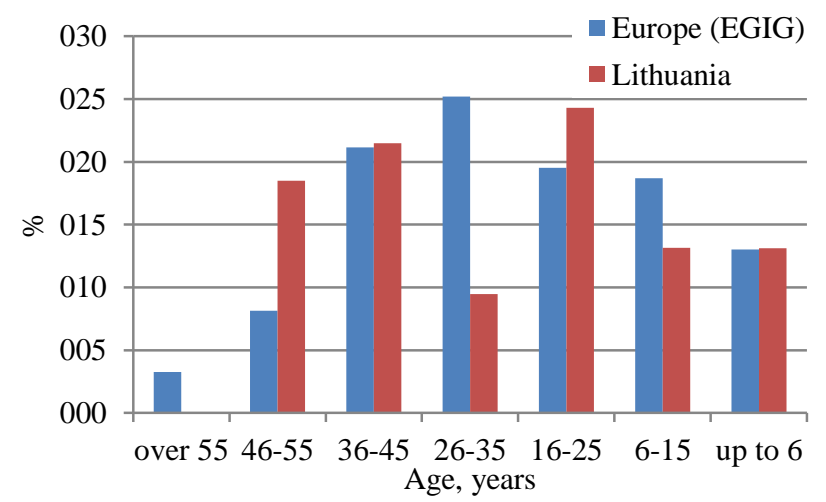

Fig. 4 Lithuanian and Western Europe (EGIP) gas transmission pipeline operation time

To compare failure causes of Lithuanian gas transmission pipeline to other databases the primary causes were divided into 6 groups as in EGIG database [1]. Causes of failures for Lithuanian gas transmission pipelines were compared to the statistical data of other countries and the analysis of failure distribution depending on the primary cause was done and is shown in Figure 6. Presented data of Lithuanian pipelines shows that distribution of gas leaks due to through-wall defects in pipeline construction/material and failure caused by corrosion are equal.

They represent the largest part of the total failure.

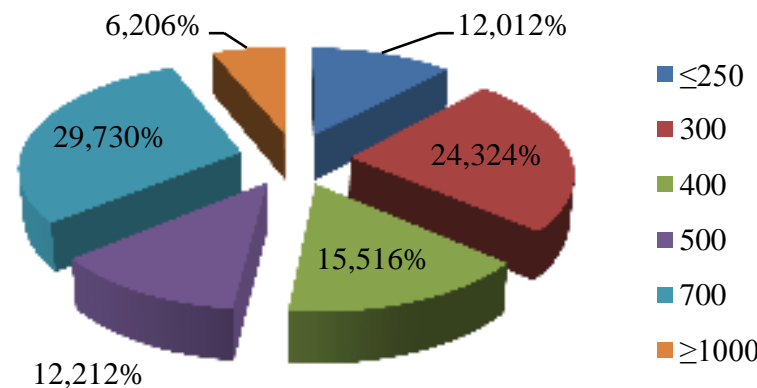

Fig. 5 Lithuanian gas transmission pipeline distribution by diameter (mm)

$60 \%$ of construction/material defects are the factory defect in the weld seam and the other $40 \%$ are breaks (possibly fatigue cracks), formed in the inner side of the elbow near to the welds. Accidents due to natural forces, such as ground movement or other, have not been identified. The majority of failures $(50 \%)$ in Russian OAO Gazprom pipeline systems are related to corrosion, but also a relatively high part $(35 \%)$ are observed of accidents caused by construction/material defects, often related to failures of the welds. Meanwhile, for example, in Western Europe (EGIG) piping main cause of failure is external interference $(48 \%)$ related to human activities. However failures caused by corrosion and construction/materials failures reach only $16 \%$ and $17 \%$. 
Lithuania (1970-2012)

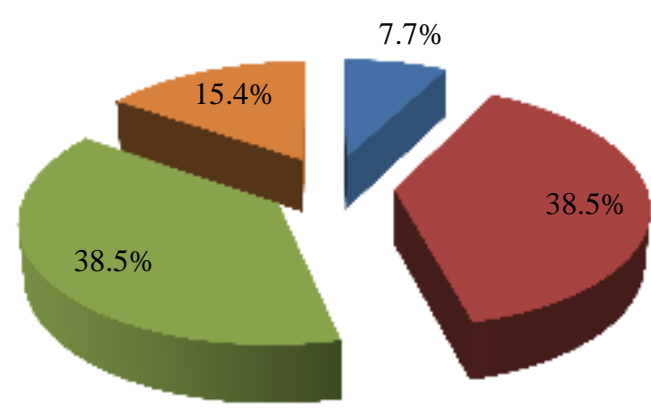

- external interference

- construction/material defects

corrosion

natural forces

- personnel mistakes

w other

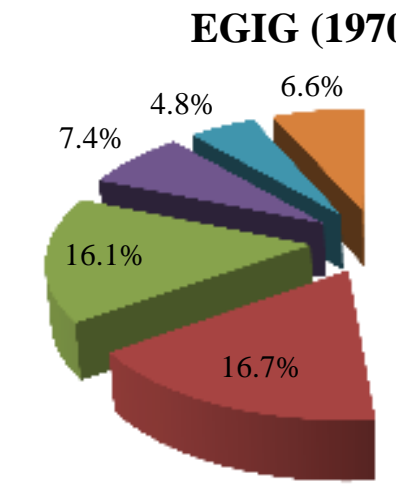

EGIG (1970-2011)

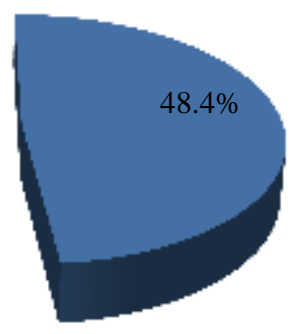

UKOPA (1962-2010)
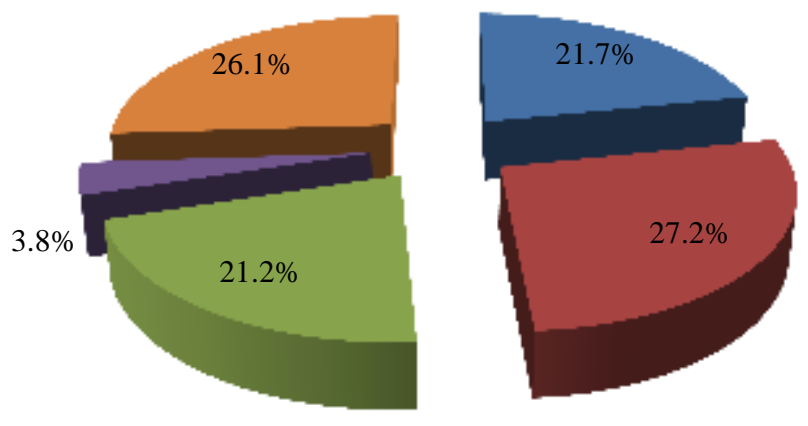

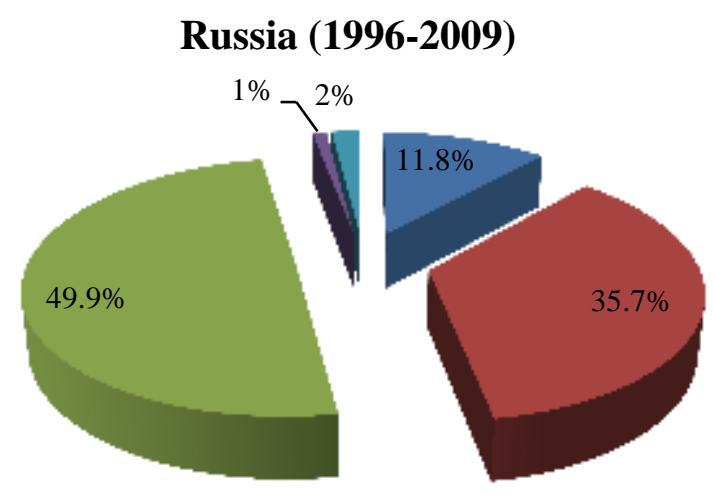

Fig. 6 Distribution of primary failure causes in gas transmission pipelines

The operational data of Lithuanian gas transmission pipeline shows that one of the main causes for through wall defects is local pitting corrosion. The typical pits of pitting corrosion which usually appears on the outer surface of the pipe are presented in the Fig. 7. Because of the relatively high density of corrosion pits in a small area the pipe wall thickness is reduced and high stress level is reached what can lead to the rupture of pipe. Typical metal microstructure under corrosion products is shown in Fig. 8. The picture shows the micro-cavities at corrosion pits whose size is close to the size of a grain. These microcavities can act as stress concentrators. In the first case, due to selective corrosion the grain boundaries can be damaged and intergranular micro-cracks can be formed. This may lead to stress corrosion. In the second case with active corrosion process and expressed electrochemical influence due to fast dissolution of the metal and low stress level stress corrosion cracks do not appear but do form wide pitting corrosion. The analysis of corrosion failures of operated pipelines shows clearly expressed second case corrosion type. During the laboratory tests of cut corroded pipe specimens the cracks attributable to stress corrosion were not detected However, according to the pipeline ruptures in Lithuania - in 2009 caused by bacteriological corrosion which mechanism is close to stress corrosion, as well as other ruptures, which cause are not known, and the Russian pipeline accidents, of which $44.6 \%$ are caused by stress corrosion [34], it is necessary to evaluate the threshold stress conditions for this type of failure. Stress corrosion may occur if stress intensity factor $K$ value in defect is greater than the threshold stress intensity factor $K_{I S C C}$. Then, under the suitable corrosive environment, the rate of induced crack growth depending on the temperature can reach $0.5-1 \mathrm{~mm} /$ year [21,35]. According to [35], to avoid this process the following condition should be complied $K \leq 21 \mathrm{MPa} \cdot \mathrm{m}^{1 / 2}$. 


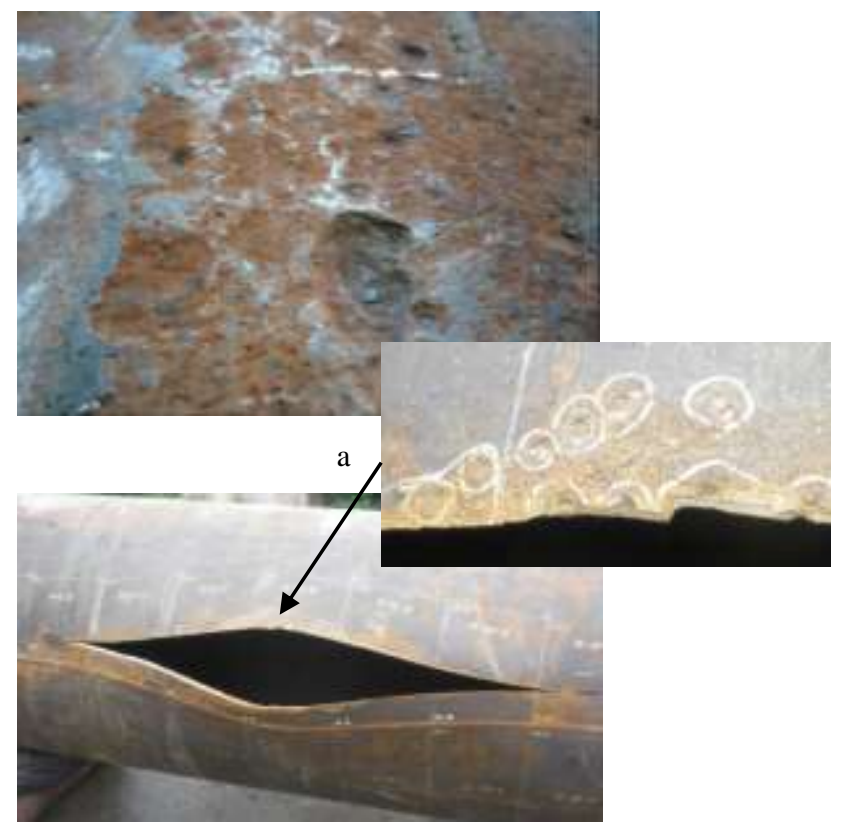

b

Fig. 7 Corrosion pits in outer surface of the pipe (a) and the pipe rupture caused by corrosion during hydraulic test (b)

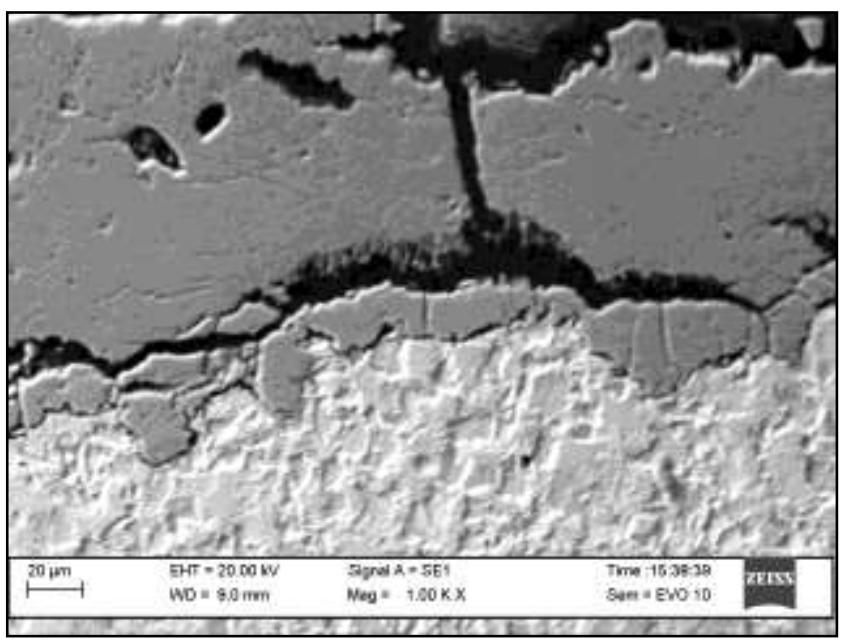

Fig. 8 Microstructure of steel at corrosion pit (1979 DN 720 X60)

\section{Fracture mechanic research of gas transmission pipeline}

Various processes and metal ageing takes place on the structure of steel pipe during the operation of gas transmission pipelines. The presented data shows that one of the main causes of failure of pipeline is the pitting corrosion which occurs in the outer surface of the pipe. Also defects/cracks are observed in the welding seams, which significant part relates to the manufacturing defects. Under complex loading and external conditions changes take place in the pipe steel. In many cases the strength of steel is changing insignificantly, however, the resistance to fracture is decreasing, i.e. the physical metal properties are getting worse what is related with deep structural changes of the steel. To evaluate the impact of aging effect to gas transmission pipelines the experimental tests were carried out. As the result the mechanical properties and fracture parameters were obtained on specimens having different operational time.

\subsection{Experimental research of mechanical properties}

In the course of this work the investigation on mechanical properties of pipe steels were done. The materials of four different pipes were received for analysis. The data on pipeline material examples are presented in $\mathrm{Ta}$ ble 2. Due to the fact that in the time when gas transmission network was built pipes properties were in accordance with GOST standard the experimental test were made also in accordance with this standard.

Experimental tests on gas transmission pipeline pipes were done at room temperature and fallowing mechanical properties were determined: yield stress $R_{p 0.2}$ ultimate strength $R_{m}$, relative elongation $A_{5}$, relative crosssection reduction and hardness $H B$.

The strength of pipe depends on hoop stress. Therefore specimens were cut in circumferential direction of the pipe. In accordance with GOST 10006-80, for preparation of specimens cut segments from pipe which diameter is $426 \mathrm{~mm}$ and over can be straightened using static load. Specimens for smaller diameter pipes are cut and tested in longitudinal direction. Dimensions and shape of specimens are selected in accordance with GOST 1000680 and GOST 1497-84.

The results of test are presented in Table 3. According to strength class (Table 4) pipe example No. 1 and 2 meet class K55 and example No. 3 meet class K42 requirements. The additional requirement $R_{p 0.2} / R_{m}<0.85$ also is met and actual strength values do not exceed their normative values more than $108 \mathrm{MPa}$.

The comparison of determined mechanical properties of steel 17GS with data of certificate No. 2761327615 of batches No. 33314, 31967 (09-11-1985) is presented in Table 5. According to presented data the ultimate strength $R_{m}$ meets the values of certificate; however the values of yield strength $R_{p 0.2}$ and relative elongation $A_{5}$ are 7-8\% lower. Also the determined carbon equivalent was CE 0.46 what is higher than given interval of 0.3-0.4 in certificate. So previously described parameters show the change material properties of pipe, which may be caused by operational conditions.

Table 2

Data of pipe samples of Lithuanian gas transmission pipeline

\begin{tabular}{|c|c|c|c|c|c|}
\hline $\begin{array}{c}\text { Pipe } \\
\text { sample } \\
\text { No. }\end{array}$ & $\begin{array}{c}\text { Pipe wall } \\
\text { thickness, } \\
\mathrm{mm}\end{array}$ & $\begin{array}{c}\text { Pipe } \\
\text { nominal } \\
\text { diameter, } \\
\mathrm{mm}\end{array}$ & Steel & $\begin{array}{c}\text { Carbon } \\
\text { Equivalent } \\
\text { CE }\end{array}$ & $\begin{array}{c}\text { In ser- } \\
\text { vice } \\
\text { since }\end{array}$ \\
\hline 1 & 9.0 & 720 & $17 \mathrm{GS}$ & 0.46 & 1986 \\
\hline 2 & 8.0 & 720 & $17 \mathrm{GS}$ & 0.39 & 1979 \\
\hline 3 & 5.5 & 159 & St2sp & 0.19 & 1968 \\
\hline
\end{tabular}


Table 3

Mechanical properties of pipe steel

\begin{tabular}{|c|c|c|c|c|c|c|}
\hline \multirow{2}{*}{$\begin{array}{c}\text { Pipe sample No. } \\
\text { (steel grade) }\end{array}$} & \multicolumn{7}{|c|}{ Mechanical properties, MPa or \% } \\
\cline { 2 - 7 } & $R_{p 0.2}$ & $R_{m}$ & $R_{p 0.2} / R_{m}$ & $A_{5}$ & $Z$ & $H B$ \\
\hline $1(17 \mathrm{GS})$ & 392.9 & 587.2 & 0.675 & 21.9 & 31.75 & 196 \\
\hline $2(17 \mathrm{GS})$ & 390.8 & 580.0 & 0.675 & 24.7 & 36.5 & 185.5 \\
\hline 3 (St2sp) & 328.0 & 420.1 & 0.78 & 21.6 & 47.1 & 151.5 \\
\hline
\end{tabular}

Mechanical properties of pipes according to pipe diameter and strength class

Table 4

\begin{tabular}{|c|c|c|c|c|}
\hline \multirow{2}{*}{ Type of pipe } & \multirow{2}{*}{ Strength class } & \multicolumn{3}{|c|}{ Mechanical properties, MPa or \% (not less than) } \\
\cline { 3 - 5 } & & $R_{p 0.2}$ & $R_{m}$ & $A_{5}$ \\
\hline \multirow{2}{*}{ Diameter $159-377 \mathrm{~mm}$} & $\mathrm{~K} 38$ & 235 & 372 & 22 \\
\cline { 2 - 5 } & $\mathrm{K} 42$ & 245 & 412 & 21 \\
\cline { 2 - 5 } & $\mathrm{K} 50$ & 343 & 485 & 20 \\
\hline \multirow{2}{*}{ Diameter 530 -820 mm } & $\mathrm{K} 52$ & 353 & 510 & 20 \\
\cline { 2 - 5 } & $\mathrm{K} 55$ & 372 & 539 & 20 \\
\cline { 2 - 5 } & $\mathrm{K} 60$ & 412 & 588 & 20 \\
\hline
\end{tabular}

Table 5

The comparison of mechanical properties of steel 17GS with data of certificate No. 27613-27615 of batches No. 33314, 31967 (09-11-1985)

\begin{tabular}{|c|c|c|c|c|c|c|c|}
\hline \multicolumn{6}{|c|}{ Mechanical properties } & \multirow{2}{*}{\multicolumn{2}{|c|}{ Carbon equivalent $\mathrm{CE}$}} \\
\hline \multicolumn{2}{|c|}{$R_{p 0.2}, \mathrm{MPa}$} & \multicolumn{2}{|c|}{$R_{m}, \mathrm{MPa}$} & \multicolumn{2}{|c|}{$A_{5}, \%$} & & \\
\hline Determined & $\begin{array}{l}\text { According to } \\
\text { certificate }\end{array}$ & Determined & $\begin{array}{l}\text { According to } \\
\text { certificate }\end{array}$ & Determined & $\begin{array}{l}\text { According to } \\
\text { certificate }\end{array}$ & Determined & $\begin{array}{l}\text { According to } \\
\text { certificate }\end{array}$ \\
\hline $391-393$ & $415-435$ & $580-587$ & $550-590$ & $22-25$ & $26-30$ & 0.46 & $0.3-0.4$ \\
\hline
\end{tabular}

\subsection{Experimental research of the stress intensity factor}

The stress intensity factors $K_{Q}$ and $K_{C}{ }^{*}$ were determined for the pipe material samples No. 1 and 2. The stress intensity factor $K_{Q}$ determined for all specimens in accordance with GOST 25.506-85 do not comply with critical stress intensity factor $K_{I C}$ conditions. Therefore critical stress intensity factor $K_{C}{ }^{*}$ for the specimen thickness, which is close to the thickness off the pipe wall, was determined. $K_{Q}$ represents the level of stress intensity factor at which area around the crack tip reach plastic strain zone due to the opening of the crack. In our case the stress intensity factor $K_{C}{ }^{*}$ determined for the thickness of the pipe wall and without corrosion products represents the critical stress intensity factor at which rupture is beginning. These factors were determined at room temperature. Compact specimens (see Fig. 9) were cut from pipe in direction that initiated crack was along pipe axis. Before determination of $K_{Q}$ and $K_{C}{ }^{*}$ factors the fatigue cracks in the specimens were formed.

The results of tests are presented in Table 6. The presented data shows that the values of stress intensity factors $K_{Q}$ and $K_{C}{ }^{*}$ of steel 17GS (example No. 1 and 2) which was in service are close to each other.

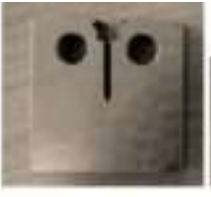

a

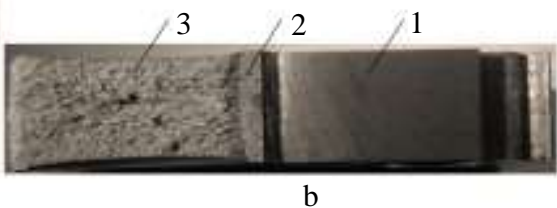

b
Fig. 9 Compact specimen (a) for determination of $K_{Q}$ and $K_{C}{ }^{*}$ factors and specimen after test (b): $1-$ machined notch, 2 - fatigue crack, 3 - fracture surface

Fracture toughness characteristics $K_{Q}, K_{C}{ }^{*}$

Table 6

\begin{tabular}{|c|c|c|c|c|c|c|c|}
\hline $\begin{array}{c}\text { Pipe sample } \\
\text { No. (steel } \\
\text { grade) }\end{array}$ & $\begin{array}{c}\text { Specimen } \\
\text { No. }\end{array}$ & $\begin{array}{c}\text { Fatigue } \\
\text { crack length } \\
\Delta a, \\
\mathrm{~mm}\end{array}$ & $\begin{array}{c}\text { Overall } \\
\text { length of } \\
\text { crack with } \\
\text { notch } a, \mathrm{~mm}\end{array}$ & $\begin{array}{l}P_{Q} \\
\mathrm{kN}\end{array}$ & $\begin{array}{l}P_{C}, \\
\mathrm{kN}\end{array}$ & $\begin{array}{c}K_{Q}, \\
\mathrm{MPa} \cdot \mathrm{m}^{1 / 2}\end{array}$ & $\begin{array}{c}K_{C}{ }^{*}, \\
\mathrm{MPa} \cdot \mathrm{m}^{1 / 2}\end{array}$ \\
\hline \multirow{3}{*}{$\begin{array}{c}1 \\
(17 \mathrm{GS})\end{array}$} & K1.1 & 1.49 & 13.5 & 10.4 & 1.2 & 67.8 & 75.9 \\
\hline & $\mathrm{K} 1.2$ & 1.52 & 13.5 & 10.3 & 1.2 & 67.7 & 75.2 \\
\hline & K1.3 & 1.76 & 13.8 & 10.2 & 1.2 & 68.7 & 80.0 \\
\hline \multicolumn{4}{|r|}{ Average value } & -- & -- & 68.1 & 77.0 \\
\hline \multirow{3}{*}{$\begin{array}{c}2 \\
(17 \mathrm{GS})\end{array}$} & K2.1 & 1.62 & 13.6 & 8.4 & 1.1 & 64.8 & 80.9 \\
\hline & $\mathrm{K} 2.2$ & 1.48 & 13.5 & 9.2 & 1.1 & 69.5 & 83.2 \\
\hline & $\mathrm{K} 2.3$ & 1.47 & 13.5 & 8.5 & 1.1 & 64.1 & 82.0 \\
\hline \multicolumn{4}{|r|}{ Average value } & -- & -- & 66.1 & 82.0 \\
\hline
\end{tabular}




\subsection{Analysis of defects in pipelines}

One section of gas transmission pipeline was selected for fracture analysis. The acceptable and critical crack sizes were determined in this analysis. The critical sizes of postulated cracks were calculated by R6 method $[36,37]$ using computer program SACC 4.0 [38]. The R6 option 1 based only on yield and tensile strength values and leads to the most conservative assessment. This method was developed by Nuclear Electric plc [39]. The main idea of this method is that crack is described by two variables $K_{r}$ and $L_{r}$. Variable $K_{r}$ is the relation between the stress intensity factor and the factor which specifies the material resistance to crack growth. Variable $L_{r}$ is the relation between the applied load and materials plasticity limit.

The analysis of acceptable and critical crack sizes was done for 12.0 and $14.3 \mathrm{~mm}$ wall thickness and $1220 \mathrm{~mm}$ in diameter pipes made of steel 17GS. The analyzed pipe section is buried underground and the only acting loads are internal pressure and deadweight if the soil. Due to combination of these loads the highest stresses in the pipe are the hoop stresses. Therefore the most dangerous axial cracks (i.e. cracks orientated along pipe axis) were analyzed. In the SACC program the experimental mechanical properties and the fracture parameters were used for analysis of acceptable and critical crack sizes. The hoop stress due to internal pressure under normal operation conditions were used as loading.

The results of analysis are presented in Figs. 10 and 11 .

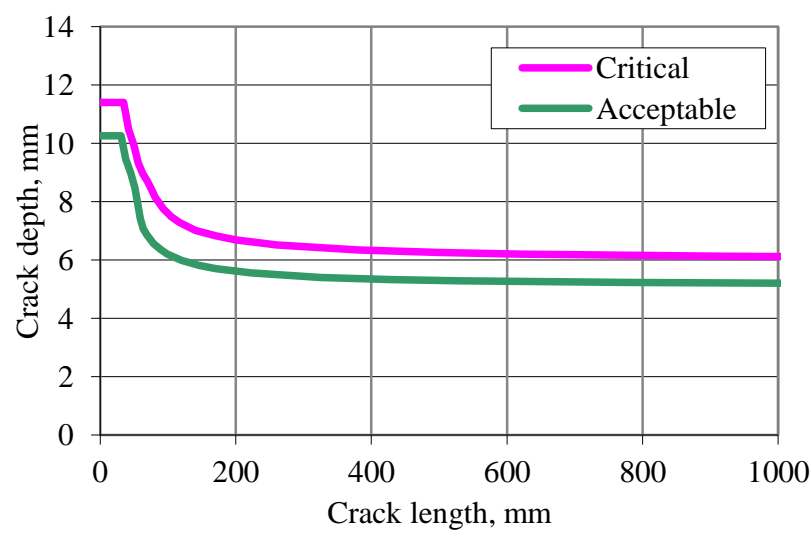

Fig. 10 Acceptable and critical crack sizes in Ø1220x14.3 pipe

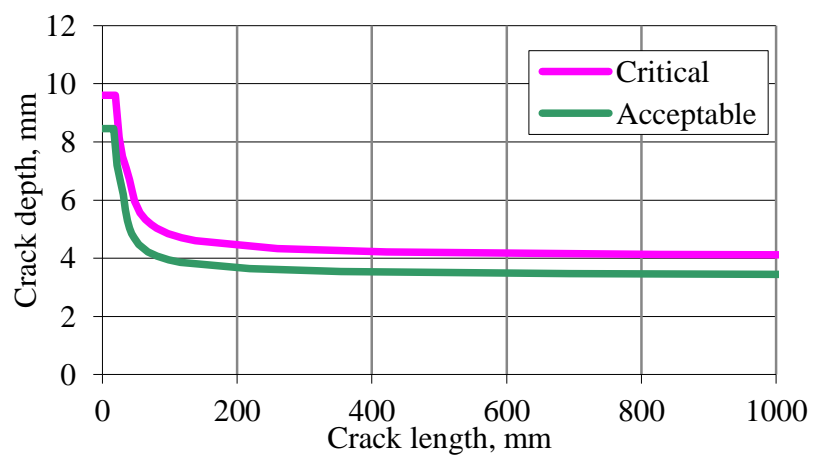

Fig. 11 Acceptable and critical crack sizes in $\varnothing 1220 \times 12$ pipe

The acceptable and critical crack size limits (i.e. crack length and crack depth) are presented in these figures. Crack which size is bigger than critical crack size curve can start to grow rapidly and that can lead to fracture of the pipe. The cracks which size is lower this curve will be stable, the rapid growth due to acting loads do not appears, and the structural integrity of the pipe will not be damaged. The cracks, which size is lower the acceptable crack size curve, are in the area limited by safety factors.

Also the stress corrosion case was analysed. The stress corrosion phenomenon is dangerous because crack growth rate is bigger than in general or pitting corrosion cases. As it was mentioned in section 3 the crack growth rate interval in stress corrosion case is $0.5-1 \mathrm{~mm} / \mathrm{year}$, $[21,36]$ and the phenomenon can occur manly in cracks orientated along the pipe axis and which stress intensity factor reach $K \geq 21 \mathrm{MPa} \cdot \mathrm{m}^{1 / 2}$ value. When this level of stress intensity factor is reached and only at proper corrosive environment properties the SCC can occur. According to data presented in the literature $[21,34]$ the average crack growth rate of $0.75 \mathrm{~mm} /$ year was selected for SCC growth analysis. The analysis results are presented in Figs. 12 and 13.

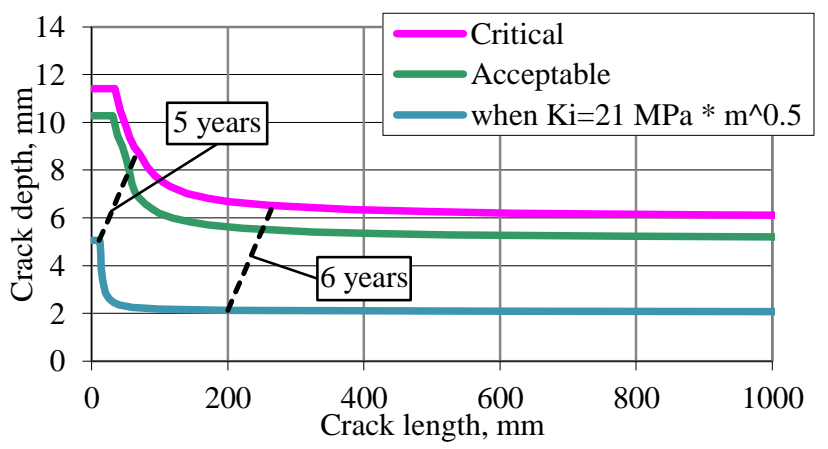

Fig. 12 Crack size limits in case of stress corrosion in Ø1220x14.3 pipe

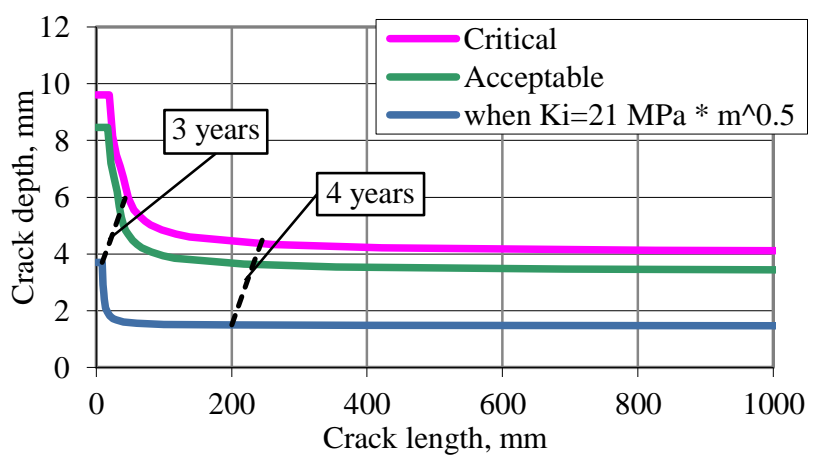

Fig. 13 Crack size limits in case of stress corrosion in $\emptyset 1220 \times 12$ pipe

These figures shows the acceptable and critical crack size limits and limit of crack sizes at which the stress intensity factor $K_{i}=21 \mathrm{MPa} \cdot \mathrm{m}^{1 / 2}$. In these figures also the prediction of defect growth is shown. This prediction shows the time in years in which the defects from initiation of SCC will reach their critical sizes. In case if SCC would be initiated the biggest cracks in pipes of $14.3 \mathrm{~mm}$ and $12 \mathrm{~mm}$ wall thickness would reach their critical values respectively in 5 and 3 years.

According to analysis results in case of stress corrosion the cracks would reach their critical values in relatively short operational time. To avoid the possibility of 
stress corrosion we recommend to repair the cracks which appear in aggressive environment and at which the stress intensity factor reach $K_{i}=21 \mathrm{MPa} \cdot \mathrm{m}^{1 / 2}$ value.

\section{Conclusions}

Analysis has shown that main causes of failures of Lithuanian gas transmission pipeline are pitting corrosion and weld defects, which mainly are manufacturing defects. In addition, the conditions were determined at which stress corrosion cracking can occur.

Element analysis and mechanical tests were done for pipes that were in operation. Mechanical and fracture toughness properties, which characterizes the resistance to crack formation, and also steel grades and steel conformity to strength class were determined.

Acceptable and critical crack sizes for gas transmission pipes at normal operation conditions were calculated. It is recommended to repair the cracks detected during inspection which sizes are higher than acceptable crack limit.

The stress corrosion case was analysed in gas transmission pipelines. According to analysis results in case of stress corrosion the cracks, which stress intensity factor $K_{i}=21 \mathrm{MPa} \cdot \mathrm{m}^{1 / 2}$, would reach their critical values in relatively short operational time. Therefore, it is recommended to remove the cracks at which stress intensity factor $K_{i}=21 \mathrm{MPa} \cdot \mathrm{m}^{1 / 2}$ is reached and thus avoid the conditions for stress corrosion.

\section{Acknowledgments}

This research was funded by a grant (No. ATE10/2010) from the Research Council of Lithuania.

\section{References}

1. 8th Report of the European Gas Pipeline Incident Data Group. EGIG 11.R.0402 (version2), December, 2011 [accessed 15 Dec. 2014]. Available from Internet: http://www.egig.eu/.

2. 8th Report of the UKOPA Fault Database Management Group. November, 2011 [accessed 17 Dec. 2014]. Available from Internet: http://www.ukopa.co.uk/.

3. PHMSA Stakeholder Communications: Pipeline Incidents and Mileage Reports [accessed 17 Dec. 2014]. Available from Internet:

http://www.phmsa.dot.gov/pipeline/library/datastatistic s/pipelineincidenttrends.

4. PHMSA Incidents Statistics [accessed 17 Dec. 2014]. Available from Internet:

http://phmsa.dot.gov/pipeline/library/datastatistics/pipel ineincidenttrends

5. PHMSA Pipeline Safety. — Flagged Incidents 200910-14[accessed 17 Dec. 2014]. Available from Internet: http://www.phmsa.dot.gov/pipeline/library/datastatistic s/flagged-data-files.

6. Annual reports on the activities of the Federal Service for Ecological, Technological and Nuclear Supervision [accessed 17 Dec. 2014]. Available from Internet: http://www.gosnadzor.ru/public/annual_reports/ (in Russian).

7. Pipeline Failure Cause / Corrosion doctors [accessed 15 Dec. 2014]. Available from Internet: http://corrosion-
doctors.org/Pipeline/Pipeline-failures.htm.

8. The State of the National Pipeline Infrastructure /US Department of Transportation [accessed 15 Dec. 2014]. Available from Internet: https://www.google.com/search?q=THE+STATE+OF+ THE+NATIONAL+PIPELINEINFRASTRUCTURE\& ie $=$ utf- $8 \&$ oe $=$ utf -8 .

9. Thompson, N.G. Gas and liquid transmission pipelines //Cost of Corrosion [accessed 15 Dec. 2014]. Available from Internet: http://corrosionda.com/pdf/gasliquid.pdf.

10. Zhila, V.A.; Aleksyutina, O.V.; Santalov, D.A. 2005. Corrosion damage influence of underground gas pipeline on reliability of gas supply systems // Journal of Plumbing, Heating and Air Conditioning (in Russian).

11. Medvedev, V.N. et al. 2006. About the causes of accident rate of gas transmission pipeline, Collection of works of a scientific-practical seminar "Problems of ageing of steel of transmission pipelines", Nizhni Novgorod, 23-25 January, 110-121p. (in Russian).

12. Miroshnichenko, B.U.; et al. 2006. Ageing of gas pipelines as a factor of stress corrosion damage of pipes, Collection of works of a scientific-practical seminar "Problems of ageing of steel of transmission pipelines", Nizhni Novgorod, 23-25 January, 132-147p. (in Russian).

13. Bakiev, A.V.; Sandakov, V.A. 2008. Change of stress in metal of gas pipeline in long operation, Oil and Gas Business 6(2): 75-76.

14. Philippov, G.A.; Litvinova, O.V. 2006. Degradation processes and their influence on fracture toughness of pipe steel in long operation, Collection of works of a scientific-practical seminar "Problems of ageing of steel of transmission pipelines", Nizhni Novgorod, 2325 January, 197-211 (in Russian).

15. Chuvildeev, V.N. 2006. Influence of ageing on operational properties of steels of gas transmission pipelines, Collection of works of a scientific-practical seminar "Problems of ageing of steel of transmission pipelines", Nizhni Novgorod, 23-25 January, 18-57 (in Russian).

16. Tkachev, V.I. 2000. Problems of hydrogen degradation of metals, Physicochemical Mechanics of Materials, 36: 7-14.

17. Bokshtein, B.S. 2006. Role of grain borders in processes of ageing of steels and alloys, Collection of works of a scientific-practical seminar "Problems of ageing of steel of transmission pipelines", Nizhni Novgorod, 23-25 January, 80-85 (in Russian).

18. Filippov, G.A.; Morozov U.D.; Chevskaja O.N. 2006. The factors influencing the tendency of pipe steel to stress corrosion cracking, Collection of works of a scientific-practical seminar "Problems of ageing of steel of transmission pipelines", Nizhni Novgorod, 2325 January, 164-177 (in Russian).

19. Nechaev, J.S. 2007. Actual problems of ageing, hydrogen embrittlement and stress-corrosion damage of steels and effective ways of their solution, Alternative power and ecology 11(55): 108-117.

20. Efimenko, L.A.; Konovalova, O.V.; Efimenko, A.M. 1999. Evaluating pipeline causes from metal structural mechanics states, Chemical and Petroleum Engineering 35: 56-58.

21. Abdullin, I.G.; Gareev, A.G.; Mostovoy, A.V. 1997. Corrosion-mechanical resistance of oil-and-gas pipeline 
system, Ufa: Gilem. 177p. (in Russian).

22. Manfredi, C.; Otegui J.L. 2002. Failures by SCC in buried pipelines, Engineering Failure Analysis 9: 495-509.

http://dx.doi.org/10.1016/S1350-6307(01)00032-2.

23. Jones, R.H. 1992. Stress-Corrosion Cracking. Materials Performance and Evaluation. - ASM International. $449 \mathrm{p}$.

24. Bruno, T.V.; Dahlberg E. 1985. Analysis of gas pipeline failures, J. Met. (United States) 37: 71-73. http://dx.doi.org/10.1007/BF03257520.

25. Baker, T.N.; Rochfort, G.G.; Parkins, R.N. 1987. Pipeline rupture - conclusion. Stress-corrosion cracking studies prompt changes in pipeline operating conditions, Oil \& Gas Journal, 37-38.

26. Mercer, W.L. 1979. Stress-corrosion cracking of mild steel in phosphate solution, Sixth Symposium on Line Pipe Research: Houston, Tex. W1-W32p.

27. Smetanin, Ph.E. et al. 2006. Resource of metal of gas pipelines in operation since 60s, Collection of works of a scientific-practical seminar "Problems of ageing of steel of transmission pipelines", Nizhni Novgorod, 2325 January. 1122-131p. (in Russian).

28. Popov, A.V.; Saruev, A.L. 2003. Structure and properties of metal of gas transmission pipeline after 30 years of operation, Oil and Gas Chemistry: Proceedings of V International Conference, Tomsk, 515-517p. (in Russian).

29. Gumerov, A.K.; Shmakov, A.K.; Khairutdinov, F.Sh. 2007. Damage mechanisms of gas transmission pipeline with welded elements, Oil and gas business [accessed 15 Dec. 2014]. Available from Internet: http://ogbus.ru/authors/GumerovAK/GumerovAK_1.pd $\mathrm{f}$ (in Russian).

30. Kolachev, B.A. 1985. Hydrogen embrittlement of metals. - M .: Metallurgy. 215p. (in Russian).

31. Zhilin A.V. 2003. The development of technical diagnostic method of electrochemical protection system of corrosion of underground steel pipelines, Oil and Gas Chemistry: Proceedings of V International Conference, Tomsk, 502-503p. (in Russian).

32. Iverson, W.P. 1987. Microbial corrosion of metals, Adv. Appl. Microbiol., 32: 1-36. http://dx.doi.org/10.1016/S0065-2164(08)70077-7.

33. Kholodenko, V.P.; Jigletsova, S.K.; Chugunov, V.A.; Rodin, V.B.; Yermolenko. Z.M. 1999. Chemicalmicrobiological diagnostics of gas pipeline sites subjected to Stress cracking corrosion, The third international conference pipelines safety: Moskow, September 6-10, 262-268p.

34. Ovcharov, S.V. 2011. About some estimation methods of accident rates of gas transmission pipelines at fire risk calculation, Safety of work in industry 2: 61-69.

35. Development of a commercial model to predict stress corrosion cracking growth rates in operating pipelines. Final Report, Contract Number: DTPH 56-08-T000001. U.S. Department of Transportation Pipeline Hazardous Materials Safety Administration. Washington, DC 20590, June 2011 [accessed 16 Dec. 2014]. Available from Internet: http://ntl.bts.gov/lib/46000/46200/46289/FilGet.pdf.

36. Anderson, T.L. 1991. Fracture mechanics. fundamentals and applications.-Boca Raton, Ana Arbor: CRC Press. 793p.

37. Milne, I.; Ainsworth, R.A.; Dowling, A.R.; Stewart, A.T. (1988). Background to and validation of CEGB report R/H/R6 - Revision 3, The International Journal of Pressure Vessels and Piping, Editor R.W. Nichols, Galliard Ltd., 32: 105-196.

38. Bergman, M. 1996. User's manual SACC Version 4.0. SAQ/FoU-Report 96/09, SAQ Kontroll AB, Stockholm, Sweden.

39. Assessment of the integrity of structures containing defects. R6-Revision 4. British Energy Generation. UK.

G. Dundulis, A. Grybėnas, R. Janulionis, R. Kriūkienė, S. Rimkevičius

\section{DEGRADATION MECHANISMS AND EVALUATION OF FAILURE OF GAS PIPELINES}

S u m m a r y

This paper presents the degradation mechanisms and their effect on lifetime of Gas Transmission Pipelines (GTP). The degradation mechanisms of US, Europe, Russian and Lithuanian GTP are presented. Lithuanian GTP is described in more detail. The experimental testing of mechanical properties and fracture parameters of selected pipelines were carried out. The fracture mechanic analysis was performed for segment of gas transmission pipeline of Lithuania. The acceptable and critical cracks sizes were determined. Also Stress Corrosion Cracking (SCC) mechanism was analysed and cracks sizes at witch SCC could be expected were determined. For simulation of defects R6 option 1 method was used.

Keywords: gas transmission pipeline, fracture toughness, stress corrosion cracking.

Received March 05, 2015 Accepted April 21, 2015 